\title{
Effects of Dissolved Organic Matter on the Co-Transport of Mineral Colloids and Sorptive Contaminants
}

\author{
Tao Cheng ${ }^{1, *}$, James Saiers $^{2}$ \\ ${ }^{1}$ Department of Earth Sciences, Memorial University of Newfoundland, St. John's, \\ Newfoundland \& Labrador, A1B 3X5, Canada \\ ${ }^{2}$ School of Forestry \& Environmental Studies, Yale University, New Haven, Connecticut, \\ 06511, USA \\ * Corresponding Author. 300 Prince Philip Drive, St. John's, Newfoundland \& Labrador, \\ A1B 3X5, Canada. \\ Phone: (709) 864-8924, Fax: (709) 864-7437, Email: tcheng@mun.ca
}




\begin{abstract}
Colloid-facilitated transport of contaminants in the vadose zone has important implications to groundwater quality, and has received considerable attention. Natural organic matter (NOM) is ubiquitous in subsurface environments, and its influence on mineral colloids and solute transport has been well documented. However, research on the influence of NOM on colloid-facilitated transport is limited. The objective of this paper is to elucidate the effects of NOM on colloid-facilitated transport of a radioactive contaminant (Cs-137) within partially-saturated sediments. Measurements made with repacked columns reveal that Cs-137 mobility was low when mineral colloids were absent and was unaffected by the presence of NOM. The addition of mineral colloids to influent increased Cs-137 mobility, and effluent Cs-137 was dominated by the colloid-associated form. When NOM was added to systems that contained mineral colloids and Cs-137, the mobility of Cs-137 further increased. A mathematical model simulating colloidfacilitated transport showed that NOM increases Cs-137 transport by increasing colloid mobility and reducing the rate of Cs-137 adsorption to the porous medium.
\end{abstract}




\section{Introduction}

Groundwater has been impacted by a variety of contaminants, many of which are discharged near land surface and enter groundwater through the vadose-zone track (Mattison et al., 2011). The transport of contaminants through the vadose zone has important implications to groundwater quality and has received considerable attention (e.g., Chen et al., 2005; Oostrom et al., 2010; Dresel et al., 2011; Lazouskaya et al., 2011; Masciopinto and Caputo, 2011; Unc et al., 2012; Lazouskaya et al., 2013). Dissolved contaminants are transported through vadose zone to groundwater by advection and dispersion, and the transport process can be retarded due to contaminant adsorption to the porous medium (Roy and Dzombak, 1997; Simunek et al., 2006; Rod et al., 2010; Gidley et al., 2012). For strongly adsorbing contaminants, the retardation is substantial and contaminant mobility could be limited if dissolved-phase transport is the only mechanism for contaminant migration. In the last few decades, it has been recognized that natural organic matter (NOM) and mineral colloids, both of which are ubiquitous in the vadose zone and groundwater, provide additional mechanisms for contaminant transport (e.g., Dunnivant et al., 1992; Kersting et al., 1999; Lowry et al., 2004; Sabbah et al., 2004; Chen et al., 2005; Cheng and Saiers, 2010; Yang et al., 2012). Mineral colloids and NOM have a high affinity for a variety of contaminants (e.g., heavy-metal ions, radionuclides, and organic molecules), and NOM and mineral colloids can, under some conditions, travel in a nearly conservative fashion or at least faster than sorptive aqueousphase contaminants. Numerous laboratory studies and field observations have confirmed that colloid- or NOM-facilitated transport is an important mechanism for contaminant migration and can greatly increase contaminant mobility (e.g., Kersting et al., 1999; 
Artinger et al., 2002a, 2002b; Utsunomiya et al., 2009; Walshe et al., 2010; Cheng and Saiers, 2010; Yin et al., 2010; Grant et al., 2011; Hartland et al., 2012).

Although extensive research has been conducted on the influence of NOM and mineral colloids on contaminant transport, fewer studies have been devoted to the synergistic effects of NOM and mineral colloids (Saiers, 2002; Tang and Weisbrod, 2009;

Walshe et al., 2010; Wang et al., 2014, 2015). In natural subsurface environments, mineral colloids, NOM, and contaminants often co-exist. Studies have shown that NOM not only enhances mobility of mineral colloids (Kretzschmar et al., 1995; Specht et al., 2000; Akbour et al., 2002; Morales et al., 2011), but also changes equilibrium and kinetics of contaminant adsorption to minerals (Ticknor et al., 1996; Kraemer et al., 2002; Saiers, 2002; Lippold and Lippmann-Pipke, 2009; Bouby et al., 2011). Therefore, it is expected that colloid-facilitated contaminant transport will be affected by NOM. To quantify contaminant mobility under natural conditions, it is important to understand how contaminant-transport behavior is altered when both NOM and mineral colloids are present.

The objective of this paper is to advance understanding of the combined effects of mineral colloids and NOM on contaminant transport. We examined the transport of mineral colloids (i.e., illite and kaolinite) and Cs-137 in the absence and presence of NOM in laboratory column experiments. The columns were packed with clean quartz sand and Hanford coarse sand (HCS) to evaluate the influence of porous-medium mineralogy on colloid and Cs-137 mobility, and the experiments were conducted under both partially-saturated and water-saturated conditions. Data from the experiments were compared with calculations of a mathematical model for colloid-facilitated contaminant 
transport in order to quantify the effects of NOM on mineral-colloid deposition and Cs137 adsorption/desorption to mobile and immobile solid phases.

\section{Laboratory Experiments}

\section{Preparation of Materials}

Porous Media. Quartz sand (Accusand, Unimin Corp) was sieved to a size range of $0.355-0.425 \mathrm{~mm}$ and washed with de-ionized water, air dried, and stored in plastic containers. Uncontaminated (Cs-137 free) Hanford coarse sand (HCS) was collected from the 200E Submarine Pit of the Hanford site. The HCS is composed predominantly of quartz sand with lesser amounts of sodium/potassium feldspar, smectite, illite, chlorite, and kaolinite. The HCS has a median grain size of $1.7 \mathrm{~mm}$, and mineral grains with dimensions between $1 \mathrm{~mm}$ and $5 \mathrm{~mm}$ compose $80 \%$ of its mass. The detailed information on HCS properties was described by Serne et al. (2002). The HCS was airdried, sieved through a $2 \mathrm{~mm}$ sieve, homogenized by manual mixing with a plastic spade, and stored in plastic containers. The median grain size of the sieved HCS was approximately $1.2 \mathrm{~mm}$, based on the HCS grain size distribution information (Serne et al., 2002).

NOM stock solution. Elliott soil humic acid (SHA) (1S102H, International Humic Substances Society) was used as a representative natural organic matter (NOM). NOM stock solution was prepared by dissolving $250 \mathrm{mg}$ SHA into one liter electrolyte solution, which contained $9.84 \mathrm{mM} \mathrm{NaCl}$ and $0.16 \mathrm{mM} \mathrm{NaHCO}_{3} . \mathrm{NaOH}$ was added to adjust the $\mathrm{pH}$ of the stock solution to 7.3. NOM stock solution was equilibrated overnight to ensure complete dissolution of the SHA. 
Background solutions. Two types of background solutions were prepared. NOMfree background solution was prepared by dissolving $\mathrm{NaCl}$ and $\mathrm{NaHCO}_{3}$ in de-ionized water. The concentrations of $\mathrm{NaCl}$ and $\mathrm{NaHCO}_{3}$ equaled 9.84 and $0.16 \mathrm{mM}$, respectively, and the $\mathrm{pH}$ of this background electrolyte solution equaled 7.3. A second type of background solution had the same $\mathrm{pH}, \mathrm{NaCl}$ and $\mathrm{NaHCO}_{3}$ concentration as the NOMfree background solution, but was amended with NOM stock solution to a NOM concentration of $5 \mathrm{mg} / \mathrm{L}$ as dissolved organic carbon (DOC).

Mineral colloid stock suspension. Illite and kaolinite colloid stock suspensions were prepared by suspending 2 grams illite powder (source clays repository) or kaolinite powder (VWR) in one liter NOM-free background electrolyte solution. The mixture was shaken vigorously, sonicated in water bath for 30 minutes, and transferred to a $1 \mathrm{~L}$ Erlenmeyer flask. After 24 hours, the clay particles remaining in suspension were siphoned into a glass bottle and stored for subsequent use. Based on Stokes law, the colloids prepared as such have a hydrodynamic diameter of $<2 \mu \mathrm{m}$ (Saiers and Hornberger, 1999). Colloid concentration in kaolinite and illite stock suspensions were determined gravimetrically by filtering $50 \mathrm{~mL}$ of the suspension through a $0.1 \mu \mathrm{m}$ membrane filter.

\section{Batch adsorption experiments}

The kinetics of Cs adsorption to quartz sand and HCS were studied using batch adsorption methods. Adsorption of Cs-137 to sand was measured as a function of time. Adsorption experiments were performed both in the presence and absence of NOM. Twenty four samples were prepared in 50-mL HDPE centrifuge tubes by adding $25 \mathrm{~g}$ of quartz sand (or $5 \mathrm{~g}$ of $\mathrm{HCS}$ ) to an electrolyte solution $(I=10 \mathrm{mM})$ containing either 0 
$\mathrm{mg} / \mathrm{L}$ or $5 \mathrm{mg} / \mathrm{L}$ DOC. Following addition of $5.6 \times 10^{-3} \mu \mathrm{mol} / \mathrm{L}$ Cs to each tube, the samples were capped and placed on a shaker table. At pre-determined time intervals (from a few minutes to $24 \mathrm{~h}$ ), two replicate sample tubes were sacrificed for each experiment. The tubes were removed from the shaker, and supernatant was withdrawn from each tube, promptly filtered through $0.2 \mu \mathrm{m}$ pore-size nylon filter, and analyzed for Cs concentration.

\section{Column experiments}

Cs transport through packed sand columns was studied in 12 experiments (Table 1). These experiments were distinguished on the basis of water saturation (partially saturated or saturated), porous media (quartz sand or HCS), concentration of DOC in pore water and influent suspension ( 0 or $5 \mathrm{mg} / \mathrm{L}$ ), concentration of mineral colloids in the influent suspension $(0 \mathrm{mg} / \mathrm{L}$ or $100 \mathrm{mg} / \mathrm{L})$, and the type of mineral colloids (kaolinite or illite) of the column influent. For experiments with no DOC (C1, C3, C5, C7, C9, C11), NOM free background solution was used for packing the column, preparing column influent solution/suspension, and during the initial flush and the flush following Cs and colloid injection. For experiments with DOC (C2, C4, C6, C8, C10, C12), a background solution with $5 \mathrm{mg} / \mathrm{L}$ DOC was used. For all the experiments, solution ionic strength and $\mathrm{pH}$ equaled $10 \mathrm{mM}$ and 7.3, respectively, mimicking those of low salinity, $\mathrm{pH}$-neutral natural groundwater.

Partially-saturated columns. Experiments with partially saturated porous media were conducted in an acrylic column measuring $5 \mathrm{~cm}$ in diameter and $10 \mathrm{~cm}$ in height. A $20 \mu \mathrm{m}$ pore-size nylon membrane was used at the bottom of the column to hold the sand and maintain capillary pressure in the column. Two peristaltic pumps, one connected to 
the top and the other one connected to the base of the column, regulated the downward flow of water through the sand-pack. Pressure head in the column was measured by tensiometers installed at 3.3 and $6.7 \mathrm{~cm}$ from the top of the column. The tensiometers were connected to a data-logger to provide a continuous record of pressure head throughout the experiments. Additional details of the column and its instrumentation are available elsewhere (Cheng and Saiers, 2009).

For each experiment, a column was packed by pouring dry-sieved quartz sand or HCS in $~ 35 \mathrm{~g}$ increments into a small volume of background solution standing in the column. After each increment of sand, the contents of the column were stirred using a stainless-steel rod and the sides of the column were tapped to mix the sand and remove air bubbles. Each quartz sand column was packed with $340 \mathrm{~g}$ sand to a height of $10 \mathrm{~cm}$, a bulk density $\left(\rho_{b}\right)$ of $1.76 \mathrm{~g} \mathrm{~cm}^{-3}$, and a porosity $(n)$ of 0.37 . Each HCS column was packed with $320 \mathrm{~g}$ sand to a height of $10 \mathrm{~cm}$, a bulk density of $1.67 \mathrm{~g} \mathrm{~cm}^{-3}$, and a porosity of 0.39 .

Partially-saturated sand columns with uniform moisture content were obtained by draining the water-saturated columns (prepared as describe above). The freshly packed water-saturated sand columns were flushed with the background electrolyte solution at a specific discharge rate $q=0.20 \mathrm{~cm} / \mathrm{min}$ for 3 pore volumes, after which the specific discharge $(q)$ at the top of the column was reduced to $0.075 \mathrm{~cm} / \mathrm{min}$ while the specific discharge $(q)$ at the base of the column was maintained at $0.20 \mathrm{~cm} / \mathrm{min}$ to drain the column. A drying front moved downward in the column during drainage. Once the drying front reached the column base, the specific discharge $(q)$ at the column base was adjusted to $0.075 \mathrm{~cm} / \mathrm{min}$, leading to the re-establishment of steady flow and uniform 
moisture content within the sand pack. The steady-state moisture content $(\theta)$ equaled 0.13 for partially-saturated quartz sand columns and 0.24 for partially-saturated HCS columns. The average linear pore water flow velocity $(q / \theta)$ in the quartz sand and HCS columns under steady-flow conditions was 0.58 and $0.31 \mathrm{~cm} / \mathrm{min}$, respectively.

The partially saturated columns were flushed at a $q=0.075 \mathrm{~cm} / \mathrm{min}$ for three pore volumes with background solution. Following this flush, a solution containing $5.6 \times 10^{-3}$ $\mu \mathrm{mol} / \mathrm{L}$ Cs-137 (C1-C4) or a suspension containing $5.6 \times 10^{-3} \mu \mathrm{mol} / \mathrm{L} \mathrm{Cs}-137$ and 100 $\mathrm{mg} / \mathrm{L}$ illite or kaolinite colloids (C5-C12) was introduced to the top of the column for a period of four hours. These Cs-spiked solutions (or suspensions) contained the same concentration of $\mathrm{NaCl}(9.84 \mathrm{mM}), \mathrm{NaHCO}_{3}(1.6 \mathrm{mM})$, and DOC $(0$ or $5 \mathrm{mg} / \mathrm{L})$ as the background solution. Upon cessation of the Cs-spiked solution/suspension, the columns were flushed with background solution without perturbing the flow rate until concentrations of colloids and Cs in the effluent samples returned to baseline levels.

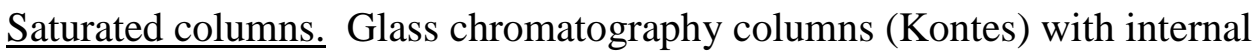
diameters of $2.5 \mathrm{~cm}$ were used for water-saturated column experiments with HCS. Each column was packed with $80 \mathrm{~g}$ HCS to a height of $10 \mathrm{~cm}$, a bulk density of $1.67 \mathrm{~g} \mathrm{~cm}^{-3}$, and a porosity of 0.39 . Teflon end-fittings were used to seal the column at the top and base. An $80 \mu \mathrm{m}$ pore-size nylon mesh was installed in the end-fitting at the base of the column to hold the sand. In the saturated column experiments, only one peristaltic pump, connected to the base of the column, was used to regulate the downward flow of water through the sand pack. Saturated experiments were conducted in a similar fashion as the unsaturated experiments, except that the drainage step was omitted. The freshly packed HCS columns were flushed at a specific discharge rate of $0.12 \mathrm{~cm} / \mathrm{min}(v=0.31 \mathrm{~cm} / \mathrm{min}$, 
same as the partially-saturated HCS columns) for 3 pore volumes, before a pulse of a suspension containing $5.6 \times 10^{-3} \mu \mathrm{mol} / \mathrm{L} \mathrm{Cs}-137$ and $100 \mathrm{mg} / \mathrm{L}$ illite in background solution was introduced to the top of the column for 4.8 hours. The pulse was followed by background solution that was applied until effluent colloid concentration returned to baseline levels.

\section{Analytical methods}

Cs-137 concentrations in the water samples were determined using a liquid scintillation counter (LS 6500, Beckman Instruments). To measure the dissolved Cs-137 concentrations of the samples, we filtered the samples through a $0.2 \mu \mathrm{m}$ pore-size nylon membrane filter (Acrodisc, Pall), and measured Cs-137 concentration of the filtrate. Results of preliminary tests showed that the mineral colloids did not pass through the filters and that dissolved Cs was not retained by the filters. The concentrations of colloid-associated Cs-137 in suspensions were computed from the difference between total and dissolved Cs-137 concentrations.

Colloid concentrations of the samples were determined by measuring the total extinction of light at a wavelength of $350 \mathrm{~nm}$ with an UV/visible spectrophotometer (DU 520, Beckman Instruments). In experiments with DOC (Table 1, C2, 4, 6, 8, 10, and 12), the DOC concentration was constant and therefore the samples had a constant light extinction caused by DOC. Our preliminary tests showed that, for samples with both mineral colloids and DOC, the difference between total light extinction and the light extinction due to DOC was equal to the light extinction caused by mineral colloids only. Therefore we subtracted light extinction caused by DOC from the total light extinction to compute mineral colloid concentration. 


\section{Modeling}

A published model for colloid-facilitated solute transport was used to help interpret the results of the column experiments (Saiers and Hornberger, 1999). The movement of colloids and Cs through the columns was simulated with separate advection-dispersion equations that were modified to account for the appropriate mass transfer reactions. Colloid immobilization was quantified as an irreversible, second-order kinetics process. The irreversibility assumption was based on our experimental observations that effluent colloid concentrations quickly dropped to zero at the end of colloid injection. Cs sorption to sand was quantified using irreversible, first-order kinetics, except for Cs sorption to quartz sand in the absence of DOC, for which secondorder kinetics model was needed because concentration of Cs adsorbed to the sand was comparable to the sand adsorption capacity for Cs. The assumption of irreversibility proved reasonable because the time scales for Cs desorption from the quartz sand and HCS were long compared to the time scales of our column experiments. Cs interactions with mineral colloids were treated as reversible, second-order kinetics reaction. The processes simulated by the model and the equations used to describe these processes are given in the Supporting Information. Values of the parameter that govern colloid deposition and Cs adsorption/desorption were estimated through inversion by minimizing the sum-of-the-squared residuals between measured and modeled colloid and Cs breakthrough concentrations using non-linear regression. Computations of the mathematical model approximated the measured colloid and Cs breakthrough curves (Fig. 2, 3, and 4), suggesting structure and assumptions of the model are appropriate for 
describing colloid deposition, Cs adsorption/deposition, and colloid and Cs transport under our experimental conditions.

\section{Results and Discussion \\ Influence of DOC on Cs adsorption to sand and mineral colloids}

Cs adsorption to sand. Measurements made in the batch experiments showed that DOC did not strongly influence the rates of Cs adsorption to the quartz sand and HCS (Fig. 1). After 24 hours, aqueous Cs concentrations in experiments with the quartz sand declined to about $40 \%$ of the initial Cs concentrations, both in the non-DOC and DOC experiments. After 24 hours in the experiments with HCS, aqueous Cs concentrations decreased to $2.5 \%$ and $3.3 \%$ of the initial Cs concentrations in non-DOC and DOC treatments, respectively.

Cs adsorption to illite and kaolinite colloids. Measurements of total and dissolved Cs concentrations in the column influent suspensions showed that DOC reduced Cs adsorption to illite and kaolinite colloids (Table 2): $95 \%$ vs. $89 \%$ of Cs was adsorbed to illite in the absence and presence of DOC, and $17 \%$ vs. 9\% of Cs was associated with kaolinite in the absence and presence of DOC. DOC lowers Cs adsorption to mineral surfaces by competing against Cs for surface sites and/or by forming aqueous DOC-Cs complexes (Kornilovich et al., 2000; Bellenger and Staunton, 2008).

\section{Cs transport in the absence of mineral colloids in partially-saturated media}

In the column experiments conducted without mineral colloids and either with or without DOC (Table 1, C1-C4), Cs was not detected in the column effluent after injecting Cs for more than 10 pore volumes (data not shown). The low Cs mobility is due 
to high Cs adsorption to quartz sand and HCS and the limited influence of DOC on Cs adsorption to the sand, consistent with the results of our batch adsorption experiments. Influence of DOC on illite and kaolinite transport through partially saturated media

Quartz sand columns. Both in the absence and presence of DOC, effluent illite concentration increased sharply during the first hour of injection and leveled off afterwards (Fig. 2 upper panels). Steady state effluent illite concentrations $\left(\mathrm{C} / \mathrm{C}_{0}\right)_{\text {illite }}$ equaled 0.90 and 0.97 in the absence and presence of DOC, respectively. Best-fit estimates of the illite deposition coefficient $\left(k_{s c}\right)$ were roughly the same for the non-DOC and DOC treatments, but the best-fit estimate of the deposition-site density $\left(s T_{c}\right)$ was greater for the experiment without DOC (Table 3).

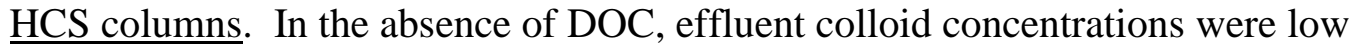
and increased gradually during colloid injection (Fig. 3). Maximum normalized effluent concentration $\left(\mathrm{C} / \mathrm{C}_{0}\right)_{\max }$ was 0.11 for illite and 0.025 for kaolinite. DOC substantially increased illite and kaolinite transport. In the presence of DOC, effluent illite concentration increased rapidly to 0.6 during the first 1 hour of injection, continued to increase slowly and approached a maximum of 0.9 immediately after termination of illite injection at $t=4$ hours. The pattern of kaolinite breakthrough in the presence of DOC was similar to that of illite, characterized by rapid initial breakthrough and subsequent slower increase in effluent concentration until the end of kaolinite injection. For both illite and kaolinite, model-estimated values of the colloid-deposition coefficient $\left(k_{s c}\right)$ were more than an order of magnitude greater for treatments without DOC than with DOC (Table 3). Estimates of the deposition site density $\left(s T_{c}\right)$ were also greater for the experiments without DOC (Table 3). 
In the absence of DOC, illite mobility in HCS columns was much lower compared to that in quartz sand columns. Our modeling results showed that this lower mobility was due to higher colloid deposition rate $\left(k_{s c}\right)$ and higher site density $\left(s T_{c}\right)$, which may arise from greater heterogeneity in surface charge (e.g., the presence of positively charged iron oxides) of natural sediments (Sheng et al., 2013), as well as nonuniformity in size and shape of the HCS, which may contribute to colloid straining or wedging. Clean quartz sand is used as the porous medium in many laboratory studies of colloid transport. Although these studies provide valuable information on how water chemistry and other factors (e.g., colloid size) influence colloid transport, colloid mobility observed in quartz sand columns is unlikely to be representative of that observed in natural subsurface environments.

The ability of DOC to increase colloid mobility has been reported previously (e.g., Kretzschmar et al., 1995; Johnson and Logan, 1996; Kretzschmar et al., 1997; Kretzschmar and Sticher, 1997; Franchi and O’Melia, 2003; Jones and Su, 2012; Wang et al., 2012; Jung et al., 2014). Our model calculation showed that DOC increases colloid mobility by decreasing deposition rate $\left(k_{s c}\right)$ and site density $\left(s T_{c}\right)$, and that the effects of DOC are more pronounced in natural sediments, in which colloid mobility would otherwise be low. The lower deposition rate in the presence of DOC is attributable to a reduction in attractive DLVO forces arising from electrostatic and/or steric effects caused by DOC adsorption to sand grain and colloids (Pensini et al., 2012, 2013). The lower site density in the presence of DOC indicates that fewer sites were available for colloid deposition due to DOC adsorption to the sand surfaces.

Influence of DOC on colloid-facilitated Cs transport through partially saturated media 
Quartz sand columns. In the absence of DOC, effluent Cs concentrations increased steadily to a maximum concentration of 0.5 during the $\mathrm{Cs}+$ illite injection (Fig 2). Our measurements showed that $95 \%$ of the influent Cs and $>96 \%$ of the effluent Cs were associated with illite (Table 2), indicating that Cs was mainly transported in colloidassociated form. Lower effluent concentration of Cs compared to that of illite (i.e., $\left.\left(\mathrm{C} / \mathrm{C}_{0}\right)_{\mathrm{Cs}}<\left(\mathrm{C} / \mathrm{C}_{0}\right)_{\text {illite }}\right)$ suggests that $\mathrm{Cs}$ desorbed from colloids during transport through the columns and adsorbed to sand. Our measurements of illite-associated Cs concentrations confirmed this Cs desorption. That is, the Cs concentration adsorbed to the influent colloids was $5.4 \times 10^{-11} \mathrm{~mol} \mathrm{Cs} / \mathrm{mg}$ colloid, while Cs concentration adsorbed to the effluent colloids ranged from $0.3-3 \times 10^{-11} \mathrm{~mol} \mathrm{Cs} / \mathrm{mg}$ colloid (Table 2).

The effects of DOC on illite-facilitated Cs transport appeared to be small in the experiments that used quartz sand as the porous medium. Breakthrough concentrations of Cs were greater in the earlier stages of the experiments with DOC, but the maximum Cs concentrations were nearly the same for experiments with and without DOC (Fig. 2, bottom panels). Consideration of the best-fit values of coefficients for Cs desorption from the colloids $\left(k_{c a}\right)$ and for Cs adsorption to the quartz sand $\left(k_{a s}\right)$ suggests that DOC modestly increased Cs mobility by decreasing both the rate of Cs desorption from the colloids and the rate of aqueous-phase Cs adsorption to the quartz sand (Table 3).

$\underline{\mathrm{HCS}}$ columns. In the non-DOC treatments, effluent Cs concentrations remained fairly low, but increased concurrently with effluent colloid concentrations during the Cs + colloid injection (Fig. 3). Maximum effluent Cs concentrations $\left(\left(\mathrm{C} / \mathrm{C}_{0}\right)_{\mathrm{Cs}}\right)$ were 0.08 for the illite treatment and 0.007 for the kaolinite treatment. DOC greatly increased Cs mobility with maximum $\left(\mathrm{C} / \mathrm{C}_{0}\right)_{\mathrm{Cs}}$ equaling 0.4 and 0.05 for the illite and kaolinite 
treatments, respectively (Fig. 3). The majority of effluent Cs in the presence of DOC was associated with colloids (Table 2). The higher Cs mobility in illite treatments compared to that in kaolinite treatments is partly attributable to higher Cs adsorption capacity of illite, as reported by previous studies (Willms et al., 2004). Cs concentrations adsorbed to the effluent colloids in the DOC experiments $\left(0.6-2.7 \times 10^{-11} \mathrm{~mol} / \mathrm{mg}\right.$ illite, $0.1-0.3$ $\times 10^{-11} \mathrm{~mol} / \mathrm{mg}$ kaolinite) were lower compared to those in the non-DOC experiments (1 $-3.7 \times 10^{-11} \mathrm{~mol} / \mathrm{mg}$ illite, $1-2 \times 10^{-11} \mathrm{~mol} / \mathrm{mg}$ kaolinite) (Table 2), indicating higher Cs desorption from colloids in the presence of DOC. In a consistent fashion, the results of the model inversions showed that the rate coefficient for Cs desorption from colloids $\left(k_{c a}\right)$ was greater in the presence of DOC (Table 3). Therefore, the much higher Cs mobility in DOC experiments compared to that in non-DOC experiments was mainly due to higher colloid mobility.

In the column experiments with mineral colloids, the best-fit estimates of the rate coefficient of Cs adsorption to HCS $\left(k_{a s}\right)$ were considerably greater for the treatments without DOC than those with DOC (Table 3), which is in qualitative agreement with the results of the batch experiments. Lower Cs adsorption to sand in the presence of DOC implies higher aqueous Cs concentration in pore water, which not only increases the mobility of aqueous Cs, but also could increase the mobility of colloid-associated Cs due to lower Cs desorption from colloids.

Although DOC increased Cs desorption from illite and kaolinite colloids and decreased Cs adsorption to the HCS, the influence of DOC on contaminant adsorption/desorption to minerals depends on the specific minerals and contaminants involved (Yang et al., 2013). Extensive studies have been conducted on how DOC 
influences contaminant adsorption/desorption to different minerals (e.g., Yang et al., 2013; Lenhart and Honeyman 1999). Results from such studies could help to predict the effects of DOC on colloid-facilitated transport under specific field conditions.

\section{Influence of moisture content on colloid and Cs transport}

Illite and Cs breakthrough curves for water-saturated HCS columns $(\theta=n=0.39)$ were similar to those for partially-saturated HCS columns $(\theta=0.24)$ (compare Fig. 4 to Fig. 3). Model calculations showed that DOC influences colloid-facilitated Cs transport in a similar way under both water-saturated and partially-saturated conditions. In both saturated and unsaturated conditions, the presence of DOC led to lower colloid deposition rates, higher rates of Cs desorption from illite, and lower Cs rates of Cs adsorption to the HCS (Table 3).

In partially-saturated media, partitioning to air-water interfaces and thin-film straining, in addition to attachment to sand surfaces, may contribute to colloid immobilization (Wan and Tokunaga, 1997; Lenhart and Saiers, 2002; Saiers and Lenhart 2003; Lazouskaya and Jin, 2008). The similar illite breakthrough in the saturated and partially-saturated columns observed in this study demonstrates that deposition onto sand surface is the dominant colloid immobilization mechanism in the partially-saturated HCS columns. The comparatively low importance of air-water interface partitioning and thin film straining is presumably due to the relatively high moisture content in the partiallysaturated HCS and the strong DLVO attractive forces between colloid and HCS grain surfaces. Under field conditions, much lower moisture content could be encountered, and air-water interface and thin film might substantially decrease colloid mobility and therefore colloid-facilitated contaminant transport (Knappenberger et al., 2014). 


\section{Environmental Implications}

Although NOM has high affinity for many contaminants (e.g., uranium) and is reported to increase the transport of such contaminants, NOM alone does not obviously promote Cs-137 transport under the conditions tested in this study. In contrast, we found that mineral colloids increased Cs-137 transport, and that NOM significantly increased mineral-colloid facilitated Cs-137 transport by increasing mineral colloid transport and decreasing Cs-137 adsorption to transport media. Although NOM also increases Cs-137 desorption from colloids, which may decrease colloid-facilitated transport, this influence was small in our experiments. The ubiquitous co-presence of mineral colloids and NOM in subsurface environments implies that NOM could potentially play a critical role in enhancing contaminant transport, even when the direct interactions between NOM and the contaminants are weak.

Acknowledgments. This work was supported by the DOE Grants DE-FG02-06ER64188 and DE-FG02-08ER6463 and National Science Foundation grant EAR1014478. 


\title{
References
}

Akbour, R. A., J. Douch, M. Hamdani and P. Schmitz (2002). "Transport of kaolinite colloids through quartz sand: Influence of humic acid, $\mathrm{Ca}^{2+}$, and trace metals." Journal of Colloid and Interface Science 253(1): 1-8.

Artinger, R., T. Rabung, J. I. Kim, S. Sachs, K. Schmeide, K. H. Heise, G. Bernhard and H. Nitsche (2002a). "Humic colloid-borne migration of uranium in sand columns." Journal of Contaminant Hydrology 58(1-2): 1-12.

Artinger, R., W. Schuessler, T. Schaefer and J. I. Kim (2002b). "A kinetic study of Am(III)/humic colloid interactions." Environmental Science \& Technology 36(20): 43584363.

Bellenger, J. P. and S. Staunton (2008). "Adsorption and desorption of (85)Sr and (137)CS on reference minerals, with and without inorganic and organic surface coatings." Journal of Environmental Radioactivity 99(5): 831-840.

\author{
Bouby, M., H. Geckeis, J. Lutzenkirchen, S. Mihai and T. Schafer (2011). "Interaction of \\ bentonite colloids with $\mathrm{Cs}, \mathrm{Eu}$, Th and $\mathrm{U}$ in presence of humic acid: A flow field-flow \\ fractionation study." Geochimica et Cosmochimica Acta 75(13): 3866-3880.
}

\author{
Chen, G., M. Flury, J. B. Harsh and P. C. Lichtner (2005). "Colloid-facilitated transport \\ of cesium in variably saturated Hanford sediments." Environmental Science \&
}


Technology 39(10): 3435-3442.

Cheng, T. and J. E. Saiers (2009). "Mobilization and transport of in situ colloids during drainage and imbibition of partially saturated sediments." Water Resources Research $\mathbf{4 5}$ : W08414.

Cheng, T. and J. E. Saiers (2010). "Colloid-facilitated transport of cesium in vadose-zone sediments: the importance of flow transients." Environmental Science \& Technology 44(19): 7443-7449.

Dresel, P. E., D. M. Wellman, K. J. Cantrell and M. J. Truex (2011). "Review: Technical and policy challenges in deep vadose zone remediation of metals and radionuclides." Environmental Science \& Technology 45(10): 4207-4216.

Dunnivant, F. M., P. M. Jardine, D. L. Taylor and J. F. McCarthy (1992). "Cotransport of cadmium and hexachlorobiphenyl by dissolved organic-carbon through columns containing aquifer mater." Environmental Science \& Technology 26(2): 360-368.

Franchi, A. and C. R. O'Melia (2003). "Effects of natural organic matter and solution chemistry on the deposition and reentrainment of colloids in porous media." Environmental Science \& Technology 37(6): 1122-1129.

Gidley, P. T., S. Kwon, A. Yakirevich, V. S. Magar and U. Ghosh (2012). "Advection 
dominated transport of polycyclic aromatic hydrocarbons in amended sediment caps." Environmental Science \& Technology 46(9): 5032-5039.

Grant, S., M. Mortimer, G. Stevenson, D. Malcolm and C. Gaus (2011). "Facilitated transport of dioxins in soil following unintentional release of pesticide-surfactant formulations." Environmental Science \& Technology 45(2): 406-411.

Hartland, A., I. J. Fairchild, J. R. Lead, A. Borsato, A. Baker, S. Frisia and M. Baalousha (2012). "From soil to cave: Transport of trace metals by natural organic matter in karst dripwaters." Chemical Geology 304: 68-82.

Johnson, W. P. and B. E. Logan (1996). "Enhanced transport of bacteria in porous media by sediment-phase and aqueous-phase natural organic matter." Water Research 30(4): 923-931.

Jones, E. H. and C. M. Su (2012). "Fate and transport of elemental copper (Cu-0) nanoparticles through saturated porous media in the presence of organic materials." Water Research 46(7): 2445-2456.

Jung, B., D. M. O’Carroll and B. E. Sleep. (2014). "The influence of humic acid and clay content on the transport of polymer-coated iron nanoparticles through sand." Science of the Total Environment 496: 155-164. 
Kersting, A. B., D. W. Efurd, D. L. Finnegan, D. J. Rokop, D. K. Smith and J. L.

Thompson (1999). "Migration of plutonium in ground water at the Nevada Test Site."

Nature 397(6714): 56-59.

Knappenberger, T., M. Flury, E. D. Mattson and J. B. Harsh (2014). "Does water content or flow rate control colloid transport in unsaturated porous media?" Environmental Science \& Technology 48(7): 3791-3799.

Kornilovich, B. Y., G. N. Pshinko and L. N. Spasenova (2000). "Effect of humics on sorption of Cs-137 by mineral components of soils." Radiochemistry 42(1): 98-102.

Kraemer, S. M., J. D. Xu, K. N. Raymond and G. Sposito (2002). "Adsorption of Pb(II) and Eu(III) by oxide minerals in the presence of natural and synthetic hydroxamate siderophores." Environmental Science \& Technology 36(6): 1287-1291.

Kretzschmar, R., D. Hesterberg and H. Sticher (1997). "Effects of adsorbed humic acid on surface charge and flocculation of kaolinite." Soil Science Society of America Journal 61(1): 101-108.

Kretzschmar, R., W. P. Robarge and A. Amoozegar (1995). "Influence of natural organic matter on colloid transport through saprolite." Water Resources Research 31(3): 435-445.

Kretzschmar, R. and H. Sticher (1997). "Transport of humic-coated iron oxide colloids in 
a sandy soil: Influence of $\mathrm{Ca}^{2+}$ and trace metals." Environmental Science \& Technology 31(12): 3497-3504.

Lazouskaya, V. and Y. Jin (2008). "Colloid retention at air-water interface in a capillary channel." Colloids and Surfaces A: Physicochemical and Engineering Aspects 235: 141151.

Lazouskaya, V., L. P. Wang, H. Gao, X. Y. Shi, K. Czymmek and Y. Jin (2011). "Porescale investigation of colloid retention and mobilization in the presence of a moving airwater interface." Vadose Zone Journal 10(4): 1250-1260.

Lazouskaya, V., L. P. Wang, D. Or, G. Wang, J. L. Caplan and Y. Jin (2013). "Colloid mobilization by fluid displacement fronts in channels." Journal of Colloid and Interface Science 406: 44-50.

Lenhart, J. J. and B. D. Honeyman (1999). "Uranium(VI) sorption to hematite in the presence of humic acid." Geochimica et Cosmochimica Acta 63(19/20): 2891-2901.

Lenhart, J. J. and J. E. Saiers (2002). "Transport of silica colloids through unsaturated porous media: Experimental results and model comparisons." Environmental Science \& Technology 36(4): 769-777.

Lippold, H. and J. Lippmann-Pipke (2009). "Effect of humic matter on metal adsorption 
onto clay materials: Testing the linear additive model." Journal of Contaminant

Hydrology 109(1-4): 40-48.

Lowry, G. V., S. Shaw, C. S. Kim, J. J. Rytuba and G. E. Brown (2004). "Macroscopic and microscopic observations of particle-facilitated mercury transport from new idria and sulphur bank mercury mine tailings." Environmental Science \& Technology 38(19): 5101-5111.

Masciopinto, C. and M. C. Caputo (2011). "Modeling unsaturated-saturated flow and nickel transport in fractured rocks." Vadose Zone Journal 10(3): 1045-1057.

Mattison, N. T., D. M. O’Carroll, R. K. Rowe and E. J. Petersen (2011). "Impact of porous media grain size on the transport of multi-walled carbon nanotubes." Environmental Science \& Technology 45(22): 9765-9775.

Morales, V. L., W. Zhang, B. Gao, L. W. Lion, J. J. Bisogni, B. A. McDonough and T. S. Steenhuis (2011). "Impact of dissolved organic matter on colloid transport in the vadose zone: Deterministic approximation of transport deposition coefficients from polymeric coating characteristics." Water Research 45(4): 1691-1701.

\footnotetext{
Oostrom, M., M. J. Truex, G. D. Tartakovsky and T. W. Wietsma (2010). "Threedimensional simulation of volatile organic compound mass flux from the vadose zone to groundwater." Ground Water Monitoring and Remediation 30(3): 45-56.
} 


\begin{abstract}
Pensini, E., B. E. Sleep, C. M. Yip and D. M. O’Carroll (2012). "Forces of interactions between bare and polymer coated iron and silica: effect of $\mathrm{pH}$, ionic strength and humic acids." Environmental Science \& Technology 46(24): 13401-13408.
\end{abstract}

\begin{abstract}
Pensini, E., B. E. Sleep, C. M. Yip and D. M. O’Carroll (2013). "Forces of interaction between fresh iron particles and iron oxide (magnetite): effect of water chemistry and polymer coatings." Colloids and Surfaces A: Physicochemical and Engineering Aspects
\end{abstract} 433: 104-110.

\begin{abstract}
Rod, K. A., W. Um, and M. Flury (2010). "Transport of strontium and cesium in simulated Hanford tank waste leachate through quartz sand under saturated and unsaturated flow." Environmental Science \& Technology 44(21): 8089-8094.
\end{abstract}
Roy, S. B. and D. A. Dzombak (1997). "Chemical factors influencing colloid-facilitated transport of contaminants in porous media." Environmental Science \& Technology 31(3): 656-664.

Sabbah, I., M. Rebhun and Z. Gerstl (2004). "An independent prediction of the effect of dissolved organic matter on the transport of polycyclic aromatic hydrocarbons." Journal of Contaminant Hydrology 75(1-2): 55-70.

Saiers, J. E. (2002). "Laboratory observations and mathematical modeling of colloid- 
facilitated contaminant transport in chemically heterogeneous systems." Water Resources Research 38(4): 1032.

Saiers, J. E. and G. M. Hornberger (1999). "The influence of ionic strength on the facilitated transport of cesium by kaolinite colloids." Water Resources Research 35(6): $1713-1727$.

Saiers, J. E. and J. J. Lenhart (2003). "Ionic-strength effects on colloid transport and interfacial reactions in partially saturated porous media." Water Resources Research 39(9): 1256.

Serne, R. J., Bjornstad, B. N. Schaef, H. T. Williams, B. A. Lanigan, D. C. Horton, D. G. Clayton, R. E. Mitroshkov, A. V. LeGore, V. L. O’Hara, M. J. Brown, C. F. Parker, K. E. Kutnyakov, I. V. Serne, J. N. Last, G. V. Smith, S. C. Lindenmeier, C. W. Zachara, J. M. Burke, D. B. Characterization of Vadose Zone Sediment: Uncontaminated RCRA Borehole Core Samples and Composite Samples; PNNL-13757-1; Pacific Northwest National Laboratory, U.S. Department of Energy, Richland, WA, 2002.

Sheng, C., V. Lazouskaya, H. Zhang, B. Li, Y. Jin and Y. Huang (2013). "Influence of surface chemical heterogeneity on attachment and detachment of microparticles." Colloids and Surfaces A: Physicochemical and Engineering Aspects 433: 14-29.

Simunek, J., C. M. He, L. P. Pang and S. A. Bradford (2006). "Colloid-facilitated solute 
transport in variably saturated porous media: Numerical model and experimental verification." Vadose Zone Journal 5(3): 1035-1047.

Specht, C. H., M. U. Kumke and F. H. Frimmel (2000). "Characterization of NOM adsorption to clay minerals by size exclusion chromatography." Water Research 34(16): 4063-4069.

Tang, X. Y. and N. Weisbrod (2009). "Colloid-facilitated transport of lead in natural discrete fractures." Environmental Pollution 157(8-9): 2266-2274.

Ticknor, K. V., P. Vilks and T. T. Vandergraaf (1996). "The effect of fulvic acid on the sorption of actinides and fission products on granite and selected minerals." Applied Geochemistry 11(4): 555-565.

Unc, A., M. J. Goss, S. Cook, X. D. Li, E. R. Atwill and T. Harter (2012). "Analysis of matrix effects critical to microbial transport in organic waste-affected soils across laboratory and field scales." Water Resources Research 48: W00L12.

Utsunomiya, S., A. B. Kersting and R. C. Ewing (2009). "Groundwater nanoparticles in the far-field at the Nevada Test Site: Mechanism for radionuclide transport." Environmental Science \& Technology 43(5): 1293-1298.

Walshe, G. E., L. P. Pang, M. Flury, M. E. Close and M. Flintoft (2010). "Effects of pH, 
ionic strength, dissolved organic matter, and flow rate on the co-transport of MS2

bacteriophages with kaolinite in gravel aquifer media." Water Research 44(4): 1255-1269.

Wan, J. M. and T. K. Tokunaga (1997). "Film straining of colloids in unsaturated porous media: Conceptual model and experimental testing." Environmental Science \& Technology 31(8): 2413-2420.

Wang, D. J., S. A. Bradford, R. W. Harvey, B. Gao, L. Cang and D. M. Zhou (2012). "Humic acid facilitates the transport of ARS-labeled hydroxyapatite nanoparticles in iron oxyhydroxide-coated sand." Environmental Science \& Technology 46(5): 2738-2745.

\author{
Wang, Q., T. Cheng, and Y. Wu (2014). "Influence of mineral colloids and humic \\ substances on uranium(VI) transport in water-saturated geologic porous media." Journal \\ of Contaminant Hydrology 170: 76-85.
}
Wang, Q., T. Cheng, and Y. Wu (2015). "Distinct roles of illite colloid and humic acid in mediating arsenate transport in water-saturated sand columns." Water, Air, \& Soil Pollution (in press).

\begin{abstract}
Willms, C., Z. H. Li, L. Allen and C. V. Evans (2004). "Desorption of cesium from kaolinite and illite using alkylammonium salts." Applied Clay Science 25(3-4): 125-133.
\end{abstract}

Yang, Y., J. E. Saiers, N. Xu, S. G. Minasian, T. Tyliszczak, S. A. Kozimor, D. K. Shuh 
and M. O. Barnett (2012). "Impact of natural organic matter on uranium transport through saturated geologic materials: from molecular to column scale." Environmental Science \& Technology 46(11): 5931-5938.

\author{
Yang, Y., J. E. Saiers, and M. O. Barnett (2013). "Impact of interactions between natural \\ organic matter and metal oxides on the desorption kinetics of uranium from \\ heterogeneous colloidal suspensions." Environmental Science \& Technology 47(6): \\ 2661-2669. \\ Yin, X. Q., B. Gao, L. Q. Ma, U. K. Saha, H. M. Sun and G. D. Wang (2010). "Colloid- \\ facilitated $\mathrm{Pb}$ transport in two shooting-range soils in Florida." Journal of Hazardous \\ Materials 177(1-3): 620-625.
}


Table 1. Summary of column experiments. Cs concentrations in the influent solution/suspension equaled $5.6 \times 10^{-3} \mu \mathrm{mol} / \mathrm{L}$ for all experiments. The solution ionic strength and $\mathrm{pH}$ equaled $10 \mathrm{mM}$ and 7.3 , respectively.

\begin{tabular}{|l|l|l|l|l|l|l|}
\hline $\begin{array}{l}\text { Experiment } \\
\text { ID }\end{array}$ & $\begin{array}{l}\text { Water } \\
\text { saturation }\end{array}$ & $\begin{array}{l}\text { Porous } \\
\text { medium }\end{array}$ & Injected species & $\begin{array}{l}\text { Colloid } \\
\text { type }\end{array}$ & $\begin{array}{l}\text { Colloid } \\
\text { conc. } \\
\text { (mg/L) }\end{array}$ & $\begin{array}{l}\text { DOC } \\
\text { conc. } \\
\text { (mg/L) }\end{array}$ \\
\hline C1 & unsaturated & quartz sand & Cs & & 0 & 0 \\
\hline C2 & unsaturated & quartz sand & Cs +DOC & & 0 & 5 \\
\hline & & & & & & \\
\hline C3 & unsaturated & HCS & Cs & & 0 & 0 \\
\hline C4 & unsaturated & HCS & Cs +DOC & & 0 & 5 \\
\hline & & & & & & \\
\hline C5 & unsaturated & quartz sand & Cs + illite & illite & 100 & 0 \\
\hline C6 & unsaturated & quartz sand & Cs + illite +DOC & illite & 100 & 5 \\
\hline & & & & & & \\
\hline C7 & unsaturated & HCS & Cs + illite & illite & 100 & 0 \\
\hline C8 & unsaturated & HCS & Cs + illite + DOC & illite & 100 & 5 \\
\hline & & & & & & \\
\hline C9 & unsaturated & HCS & Cs + kaolinite & kaolinite & 100 & 0 \\
\hline C10 & unsaturated & HCS & Cs + kaolinite +DOC & kaolinite & 100 & 5 \\
\hline & & & & & & \\
\hline C11 & saturated & HCS & Cs + illite & illite & 100 & 0 \\
\hline C12 & saturated & HCS & Cs + illite + DOC & illite & 100 & 5 \\
\hline
\end{tabular}

${ }^{1}$ Refers to the concentration of DOC in the injection solution and in the background solution used to equilibrate and flush the columns. 
Table 2. Percentage of colloid-associated Cs in the influent and effluent, and concentrations of Cs adsorbed to the colloids from column influent and effluent samples. Effluent percentages and sorbed concentrations reflect the ranges measured during the course of the column experiments.

\begin{tabular}{|c|c|c|c|c|c|}
\hline Experiment ID & $\begin{array}{l}\text { influent } \\
\text { total Cs } \\
\text { conc. } \\
\left(10^{-9} \mathrm{~mol} / \mathrm{L}\right)\end{array}$ & $\begin{array}{l}\text { influent } \\
\% \text { of Cs } \\
\text { associated } \\
\text { with colloid }\end{array}$ & $\begin{array}{l}\text { effluent } \\
\% \text { of Cs } \\
\text { associated } \\
\text { with colloids }\end{array}$ & $\begin{array}{l}\text { influent } \\
\text { Cs conc. on } \\
\text { colloids } \\
\left(10^{-11} \mathrm{~mol} / \mathrm{mg}\right)\end{array}$ & $\begin{array}{l}\text { effluent } \\
\text { Cs conc. on } \\
\text { colloids } \\
\left(10^{-11} \mathrm{~mol} / \mathrm{mg}\right)\end{array}$ \\
\hline $\begin{array}{l}\text { C5 } \\
\text { (quartz sand, illite, no DOC) }\end{array}$ & 5.6 & $95 \%$ & $>96 \%$ & 5.4 & $0.3-3$ \\
\hline $\begin{array}{l}\text { C6 } \\
\text { (quartz sand, illite, DOC) }\end{array}$ & 5.6 & $89 \%$ & $>95 \%$ & 4.9 & $0.5-3.5$ \\
\hline $\begin{array}{l}\text { C7 } \\
\text { (HCS, illite, no DOC) }\end{array}$ & 5.6 & $95 \%$ & $80 \%-90 \%$ & 5.4 & $1-3.7$ \\
\hline $\begin{array}{l}\text { C8 } \\
\text { (HCS, illite, DOC) }\end{array}$ & 5.6 & $89 \%$ & $65 \%-93 \%$ & 4.9 & $0.6-2.7$ \\
\hline $\begin{array}{l}\text { C9 } \\
\text { (HCS, kaolinite, no DOC) }\end{array}$ & 5.6 & $17 \%$ & $\sim 100 \%$ & 1 & $1-2$ \\
\hline $\begin{array}{l}\text { C10 } \\
\text { (HCS, kaolinite, DOC) }\end{array}$ & 5.6 & $9 \%$ & $54 \%-65 \%$ & 0.55 & $0.1-0.3$ \\
\hline $\begin{array}{l}\text { C11 } \\
\text { (saturated HCS, illite, no DOC) }\end{array}$ & 5.6 & $95 \%$ & $80 \%-90 \%$ & 5.4 & $1-3.7$ \\
\hline $\begin{array}{l}\mathrm{C} 12 \\
\text { (saturated HCS, illite, DOC) }\end{array}$ & 5.6 & $89 \%$ & $65 \%-93 \%$ & 4.9 & $0.6-2.7$ \\
\hline
\end{tabular}


Table 3. Model calculated colloid deposition rate coefficient $\left(k_{s c}\right)$, site density for colloid deposition $\left(s T_{c}\right)$, rate coefficient for Cs desorption from colloids $\left(k_{c a}\right)$, and rate coefficient for Cs adsorption to sand $\left(k_{a s}\right)$.

\begin{tabular}{|c|c|c|c|c|c|c|c|}
\hline Experiment ID & \multicolumn{3}{|c|}{ colloid } & \multicolumn{4}{|c|}{ Cs } \\
\hline 10 & $\begin{array}{l}k_{s c} \\
\text { (1/hour) }\end{array}$ & $\begin{array}{l}s T_{c} \\
(\mathrm{mg} / \mathrm{g})\end{array}$ & $\mathrm{r}^{2}$ & $\begin{array}{l}k_{c a} \\
\text { (1/hour) }\end{array}$ & $\begin{array}{l}k_{\text {as }} \\
\text { (1/hour) }\end{array}$ & $\begin{array}{l}s T_{a} \\
(\mu \mathrm{g} / \mathrm{g})\end{array}$ & $\mathrm{r}^{2}$ \\
\hline $\begin{array}{l}1255 \\
13 \text { quartz sand, } \\
14 \text { llite, no DOC) }\end{array}$ & $0.36 \pm 0.12$ & $0.38 \pm 7.69$ & 0.93 & $8.94 \pm 1.56$ & $157.50 \pm 18.57$ & $10^{-6}$ & 0.88 \\
\hline $\begin{array}{l}156 \\
16 \text { quartz sand, } \\
17 \text { llite, DOC) }\end{array}$ & $0.32 \pm 0.09$ & $0.01 \pm 0.004$ & 0.97 & $7.51 \pm 0.92$ & $38.63 \pm 2.52$ & Not applicable & 0.95 \\
\hline (8) & $11.10 \pm 0.38$ & $0.26 \pm 0.01$ & 0.92 & $2.59 \pm 1.02$ & $249.68 \pm 46.73$ & Not applicable & 0.91 \\
\hline $\begin{array}{l}58 \\
5 \text { HCS, illite, } \\
\end{array}$ & $0.87 \pm 0.13$ & $0.04 \pm 0.01$ & 0.91 & $3.46 \pm 0.91$ & $43.60 \pm 10.63$ & Not applicable & 0.91 \\
\hline $\begin{array}{l}269 \\
6 \mathrm{HCS}, \text { kaolinite, } \\
280 \text { DOC) }\end{array}$ & $22.25 \pm 1.75$ & $0.37 \pm 0.05$ & 0.76 & $0.35 \pm 0.31$ & $35.00 \pm 4.36$ & Not applicable & 0.83 \\
\hline $\begin{array}{l}2910 \\
30 \mathrm{HCS}, \text { kaolinite, } \\
\text { \$DOC) }\end{array}$ & $1.81 \pm 0.11$ & $0.07 \pm 0.004$ & 0.96 & $1.74 \pm 0.37$ & $21.51 \pm 2.95$ & Not applicable & 0.80 \\
\hline 32 & & & & & & & \\
\hline $\begin{array}{l}\text { 3511 } \\
\text { 34saturated HCS, } \\
\text { 35llite, no DOC) }\end{array}$ & $17.70 \pm 2.73$ & $0.32 \pm 0.03$ & 0.67 & $3.56 \pm 2.11$ & $289.60 \pm 119.39$ & Not applicable & 0.72 \\
\hline $\begin{array}{l}\text { \$612 } \\
\text { 37saturated HCS, } \\
\text { 38llite, DOC) }\end{array}$ & $0.91 \pm 0.15$ & $0.02 \pm 0.002$ & 0.97 & $5.68 \pm 1.97$ & $31.46 \pm 5.39$ & Not applicable & 0.86 \\
\hline
\end{tabular}


Figure 1. Kinetics of Cs adsorption to quartz sand and HCS. In both the quartz sand and HCS experiments, initial Cs concentration, $\left[\mathrm{Cs}^{+}\right]_{0}$, equaled $5.6 \times 10^{-3} \mu \mathrm{mol} / \mathrm{L}$ and the solution ionic strength and $\mathrm{pH}$ equaled $10 \mathrm{mM}$ and 7.3 , respectively. The solid-tosolution ratio was $25 \mathrm{~g} / \mathrm{L}$ for quartz sand experiments and $5 \mathrm{~g} / \mathrm{L}$ for HCS experiments. $\left[\mathrm{Cs}^{+}\right]$is concentration of Cs remaining in solution at time $t$.

\section{quartz sand}

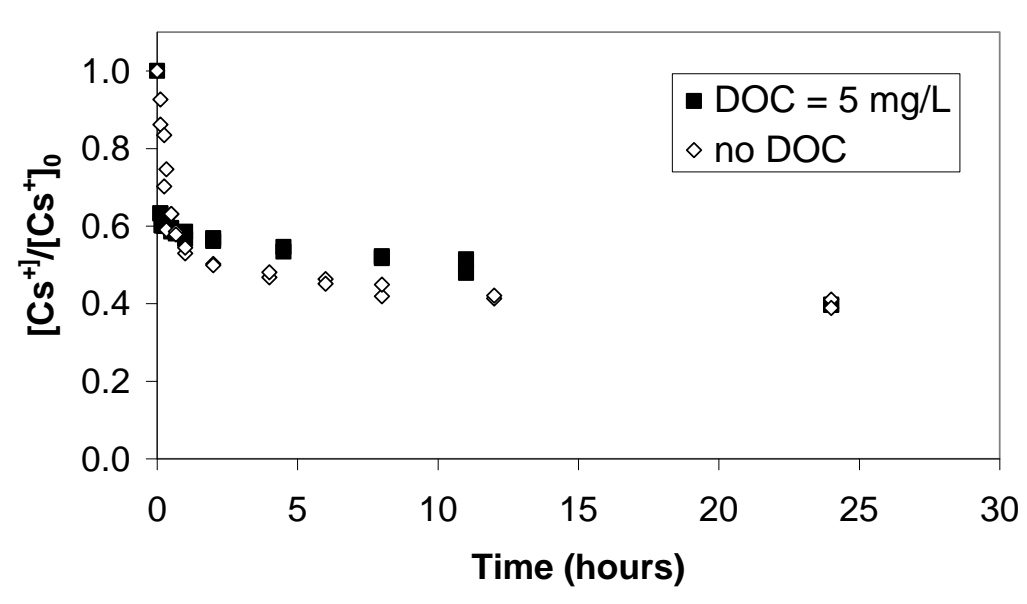

HCS

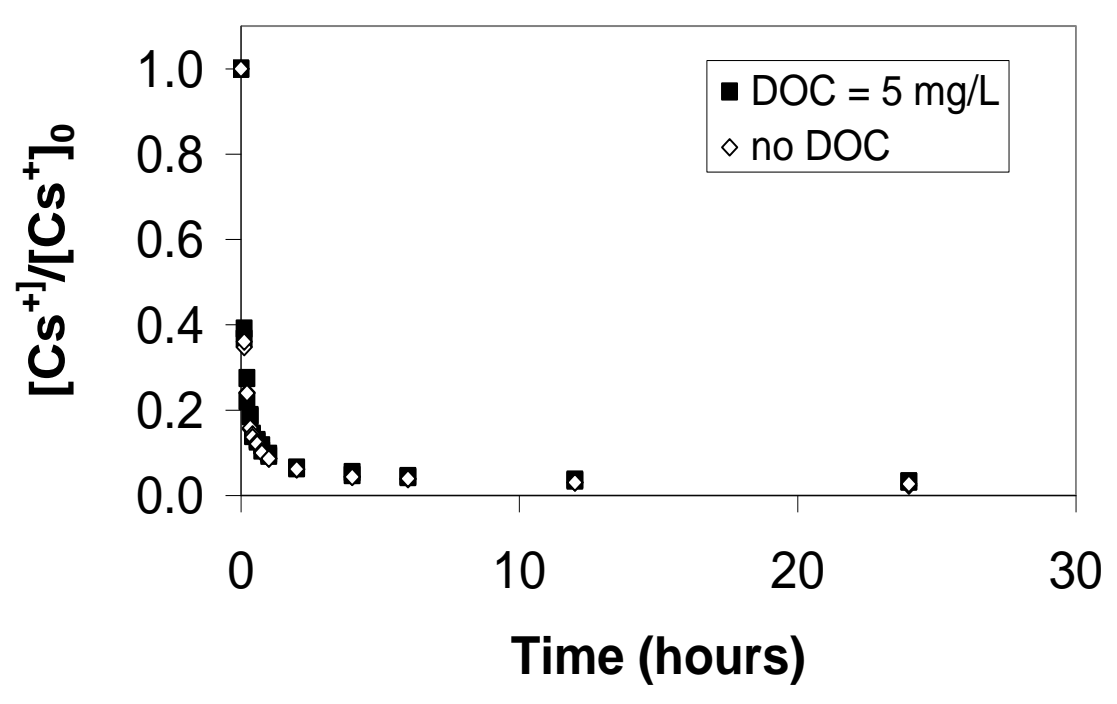


Figure 2. Measured (symbols) and calculated (lines) breakthrough curves of illite colloids (upper panels) and Cs (lower panels) in partially-saturated quartz sand columns. Text in the parentheses refers to Experiment ID listed in Table 1. Pore volume equals $q t /(L \theta)$, where $q$ is specific discharge. $L$ is column length, $\theta$ is moisture content, and $t$ is time.

Quartz sand, no DOC (C5)
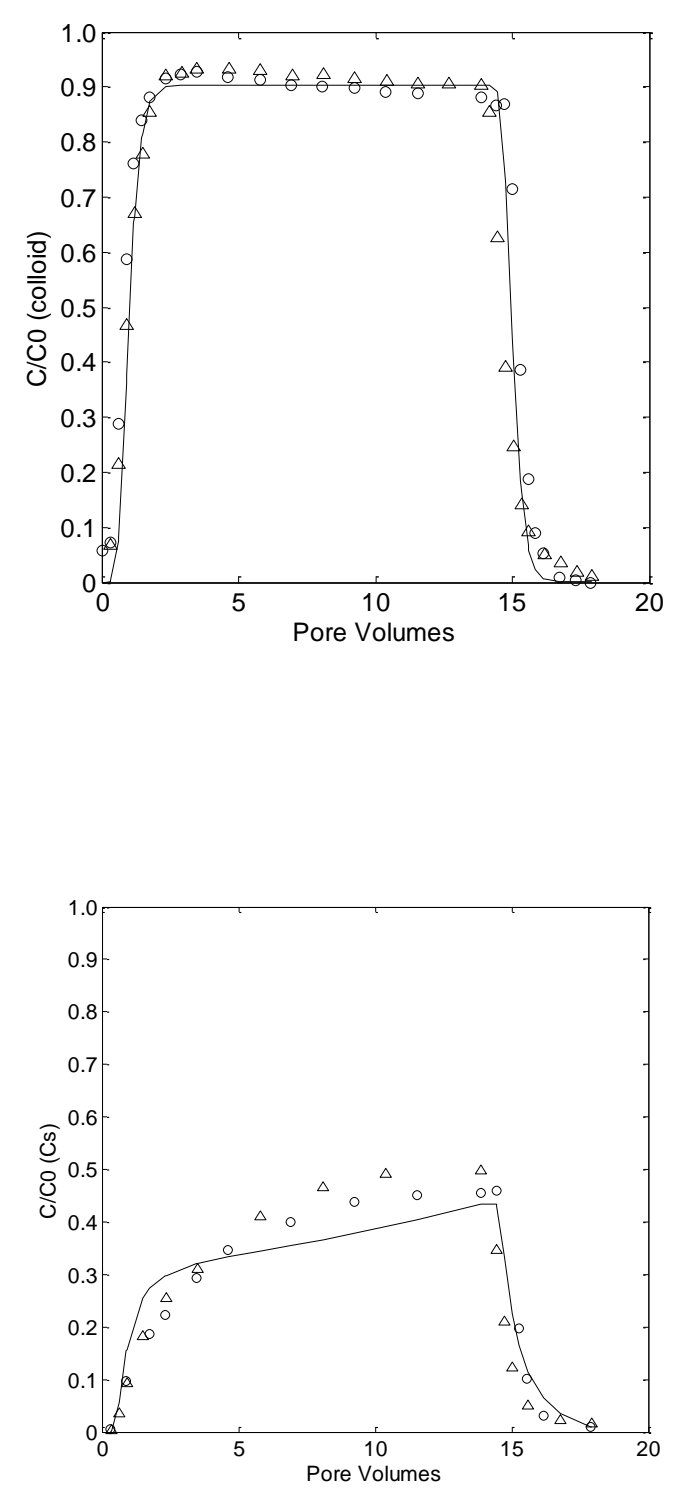

\section{Quartz sand, with DOC}

(C6)
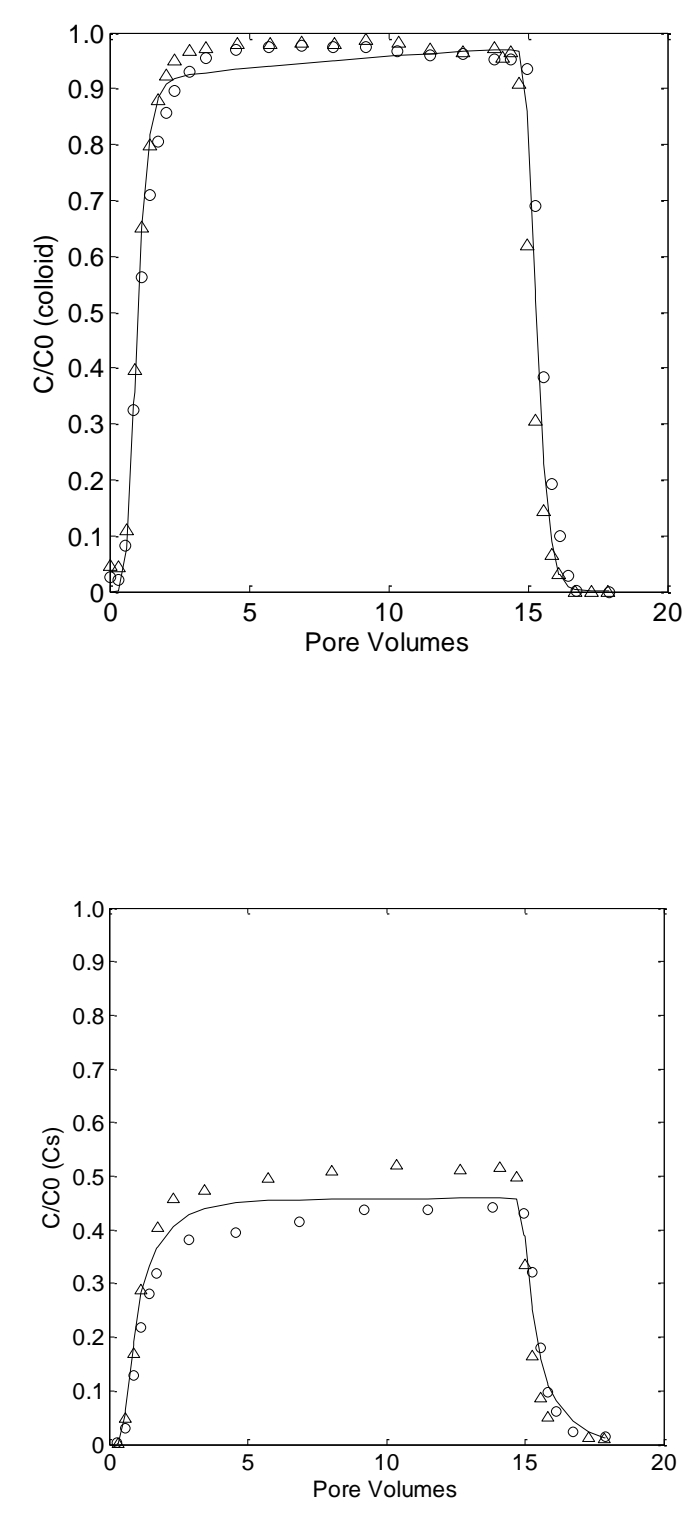
Figure 3. Measured (symbols) and calculated (lines) breakthrough curves of illite/kaolinite colloids (upper panels) and Cs (lower panels) in partially-saturated HCS columns. Text in the parentheses refers to Experiment ID in Table 1. Pore volume equals $q t /(L \theta)$, where $q$ is specific discharge. $L$ is column length, $\theta$ is moisture content, and $t$ is time.
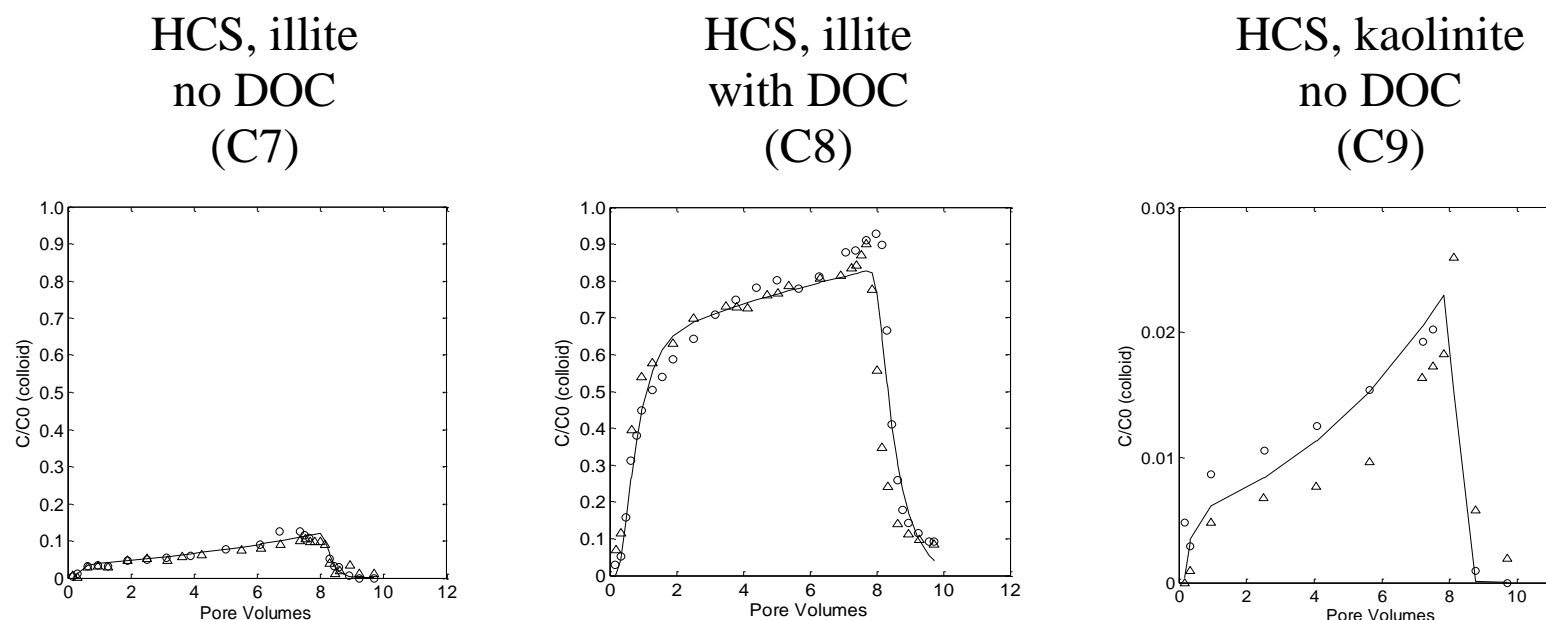
HCS, kaolinite with DOC
(C10)
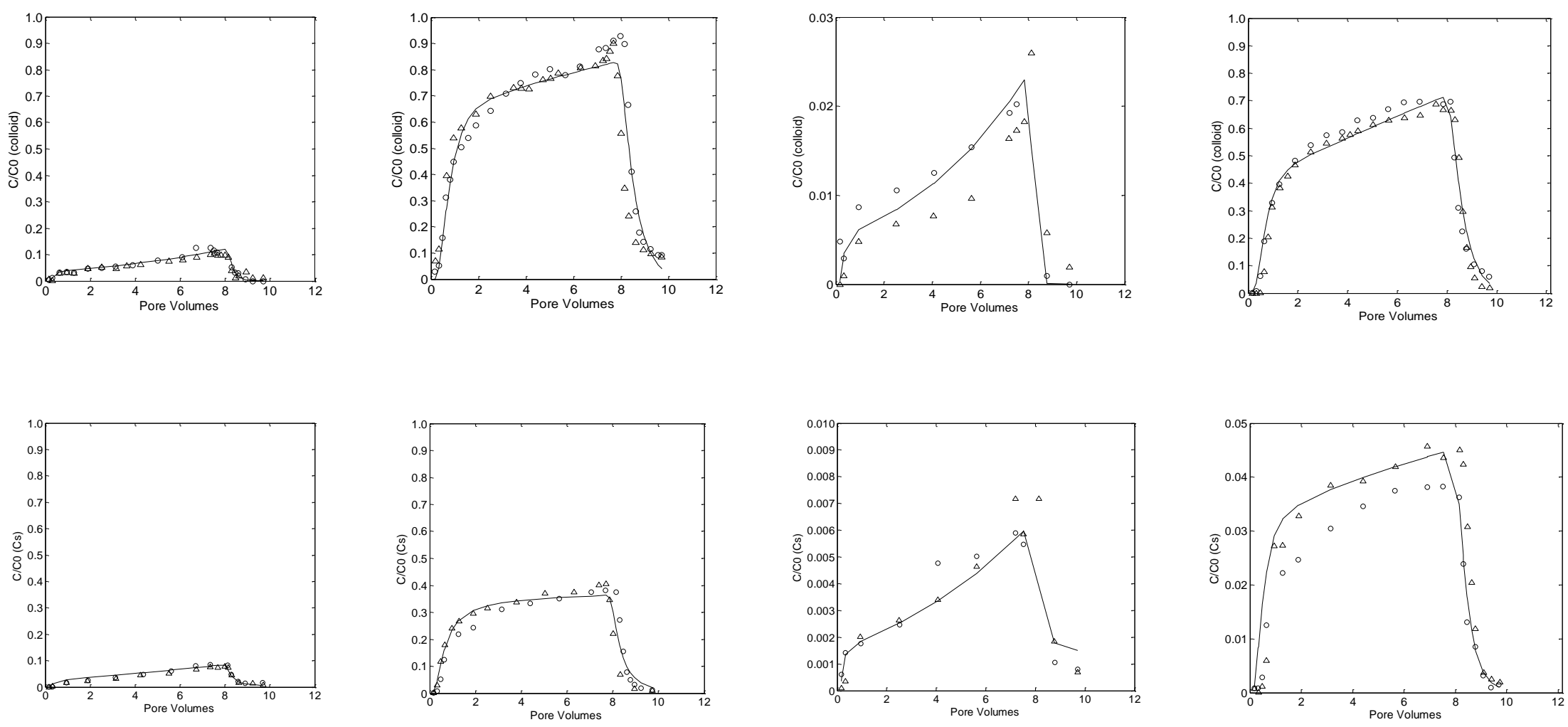
Figure 4. Measured (symbols) and calculated (lines) breakthrough curves of illite colloids (upper panels) and Cs (lower panels) in water-saturated HCS columns. Text in the parentheses refers to Experiment ID in Table 1. Pore volume equals $q t /(L \theta)$, where $q$ is specific discharge. $L$ is column length, $\theta$ is moisture content, and $t$ is time.

\section{Saturated HCS, illite no DOC (C11)}
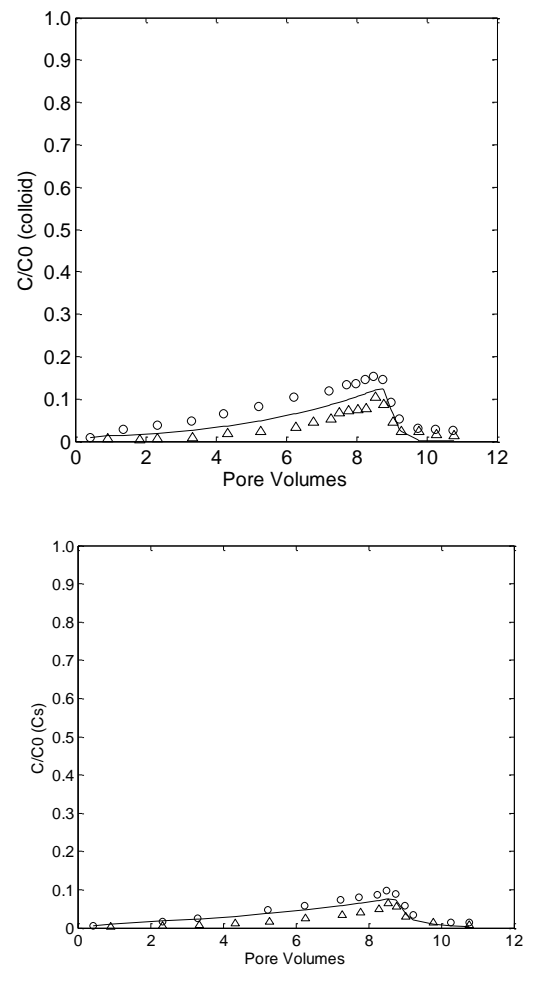

Saturated HCS, illite with DOC (C12)
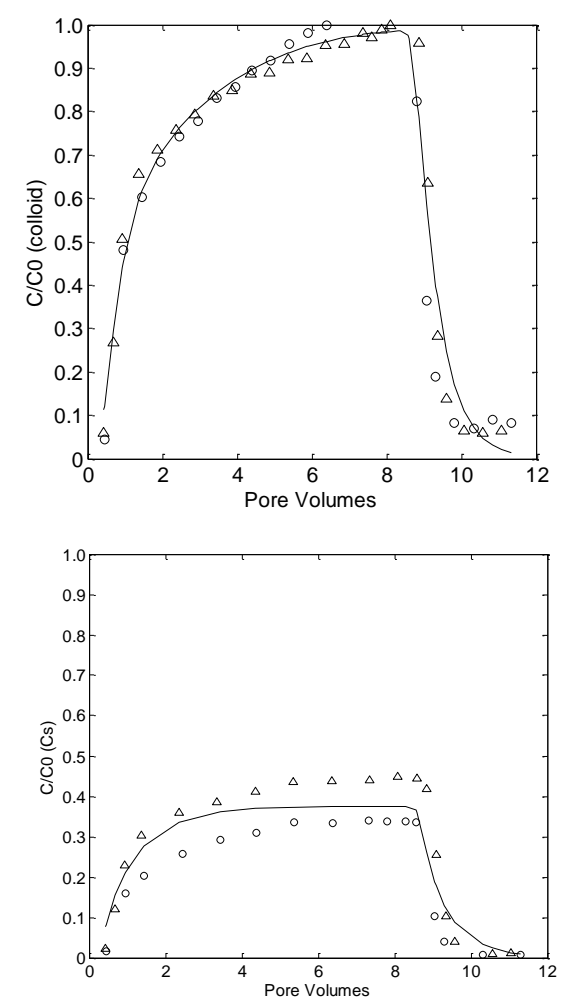